\title{
PRODUCTIVITY AND TECHNOLOGICAL VALUE OF SPRING WHEAT IN CONDITIONS OF AUTUMN SOWING DATE
}

\author{
Jerzy Grabinski, Marta Wyzinska \\ Institute of Soil Science and Plant Cultivation State Research Institute in Pulawy, Poland \\ mail_mwyzinska@iung.pulawy.pl,jurek@iung.pulawy.pl
}

\begin{abstract}
Two forms of wheat are cultivated in Poland: winter and spring. At the same time, the spring form is much less popular, which results mainly from its lower yields. A very important advantage of spring wheat is its higher quality of grain than of winter wheat, although it should be emphasized that this fact is now less important than in the past decades. At the end of the 20th century, some Polish cereal growers began to advertise their spring cultivars as suitable also for autumn sowing. This prompted field experiments to be carried out in several research centers to check this trait for the cultivars indicated by the growers. Field tests were carried out in three growing seasons 2008/2009, 2009/2010 and 2010/2011 at the Experimental Station for Cultivar Assessment in Cicibór Duży, Poland. The research was based on two-factor field experiments, established with the method of split-plot, in four replications. The first factor (A) was sowing date: the first (I) - autumn (2-3 weeks later than specified in the agrotechnical recommendations of IUNG-PIB, as an admissible delay for winter wheat), the second (II) - autumn (delayed compared to the first by 1-3 weeks), the third (III) - spring (indicated according to the agrotechnical recommendations of IUNG-PIB for spring wheat, as the earliest possible). The second factor (B) were spring wheat cultivars: 1) Tybalt, 2) Cytra, 3) Bombona, 4) Monsun, 5) Parabola. The aim of the research was to determine the effect of sowing date on the yield, yield structure and the technological value of the grains of selected spring wheat varieties. In the years 2010 and 2011, significantly higher wheat grain yields from autumn sowing dates in relation to the spring date were found. Wheat sown in autumn was also characterized by higher production tillering, weight of 1000 grains, weight of grains per plant. On the basis of the performed qualitative analyses of wheat grain, no significant influence of the sowing date on the falling number and gluten index was found.
\end{abstract}

Keywords: yield, wheat, sowing, value.

\section{Introduction}

Two forms of wheat are cultivated worldwide: winter and spring. Spring form of wheat is much less popular because it yields less. Reduced spring wheat fertility compared to the winter form is mainly due to its shorter growing season and lower resistance to spring droughts, which affect various regions of Poland almost every year. In the past decade, some cereal growers in Poland started to advertise their spring cultivars as useful also for autumn sowing. This triggered field experiments in several research centres to test this feature for the cultivars indicated by the growers, but often, also other cultivars were included in these studies. It was pointed out, among other things, that sowing spring forms in autumn has many advantages, and in particular, it extends the growing season, including, first of all, the stage of tillering and stem formation [1-5]. An important advantage of such a sowing date, indicated by the authors of the above mentioned research, is also an increase in the resistance of plants to spring drought, and drought occurs basically every year during the spring vegetation of cereal [6]. According to the popular and popular-scientific press, the number of growers sowing spring cultivars in autumn is relatively high. Farmers sow spring cultivars mainly after late crops: potatoes, beet and maize, which are generally called facultative cultivars. This term has been used for these cultivars by numerous authors of scientific papers [2;7-9].

There are only a few studies in this area and they do not fully cover the issue of sowing spring cereal cultivars in the autumn. A very important advantage of spring wheat is its higher quality of grains than in the case of winter wheat. Although this fact is now less important than in the past decades, when spring wheat clearly dominated over winter cultivars in terms of quality, because among the registered winter wheat varieties, only few were characterized by genetically determined high quality of grain.

Therefore, the sowing of spring wheat varieties in the autumn time is primarily to result in higher grain yields by extending the growing season, but also can cause greater plant resistance to spring drought (plants sown in autumn have a more developed root system). 


\section{Materials and methods}

Field tests were carried out in three growing seasons 2008/2009, 2009/2010 and 2010/2011 at the Experimental Station for Cultivar Assessment (SDOO) in Cicibór Duży, belonging to the Central Centre for Crop Cultivars Research (COBORU).

The research was based on two-factor field experiments, based on the method of split-plot in four replications. The first factor (A) was the sowing date: the first (I) - autumn (later by 2-3 weeks than specified in the agrotechnical recommendations of IUNG-PIB, as an admissible delay for winter wheat), the second (II) - autumn (delayed from the first one by 1-3 weeks), the third (III) - spring (indicated in the agrotechnical recommendations of IUNG - PIB (Institute of Soil Science and Plant Cultivation - State Research Institute) for spring wheat, as the earliest possible). The second order factor (B) were spring wheat varieties: 1) Tybalt, 2) Cytra, 3) Bombona, 4) Monsun, 5) Parabola. The date of sowing, soil abundance and rate of fertilizations are presented in Tables 1-3.

The experiment was established on lessive soil, silty heavy loamy sand, soil class III b, agricultural utility complex - rye very good.

Table 1

Dates of spring wheat sowing in subsequent vegetation seasons

\begin{tabular}{|c|c|c|c|}
\hline \multirow{2}{*}{$\begin{array}{c}\text { Growing } \\
\text { season }\end{array}$} & \multicolumn{3}{|c|}{ Sowing term } \\
\cline { 2 - 4 } & I & II & III \\
\hline $2008 / 2009$ & 24.10 .2008 & 14.11 .2008 & 2.04 .2009 \\
\hline $2009 / 2010$ & 26.10 .2009 & 10.11 .2009 & 30.03 .2010 \\
\hline $2010 / 2011$ & 20.10 .2010 & 5.11 .2010 & 30.03 .2011 \\
\hline
\end{tabular}

Soil abundance (mg per $100 \mathrm{~g})$ by year

\begin{tabular}{|c|c|c|c|c|}
\hline $\begin{array}{c}\text { Year of } \\
\text { harvest }\end{array}$ & $\mathbf{P}_{\mathbf{2}} \mathbf{O}_{\mathbf{5}}$ & $\mathbf{K}_{\mathbf{2}} \mathbf{O}$ & $\mathbf{M g}$ & $\mathbf{p H}$ \\
\hline 2009 & 20.1 & 26.3 & 4.8 & 6.35 \\
\hline 2010 & 20.1 & 27.7 & 4.5 & 6.86 \\
\hline 2011 & 31.0 & 24.7 & 6.0 & 6.24 \\
\hline
\end{tabular}

Prior to sowing, the grain was primed with appropriate seed treatments, recommended for winter cereals. The area of the plot to be harvested was $15 \mathrm{~m}^{2}$.

Rates of minerals in growing seasons

Table 3

\begin{tabular}{|c|c|c|c|}
\hline $\begin{array}{c}\text { Growing } \\
\text { season }\end{array}$ & $\mathbf{N}, \mathbf{k g} \cdot \mathbf{h a}^{\mathbf{- 1}}$ & $\mathbf{P}_{\mathbf{2}} \mathbf{O}_{\mathbf{5}}, \mathbf{k g} \cdot \mathbf{h a} \mathbf{-}^{\mathbf{- 1}}$ & $\mathbf{K}_{\mathbf{2}} \mathbf{O}, \mathbf{k g} \cdot \mathbf{h a} \mathbf{-}^{-\mathbf{1}}$ \\
\hline $2008 / 2009$ & 85 & 35 & 40 \\
\hline $2009 / 2010$ & 119 & 33 & 33 \\
\hline $2010 / 2011$ & 125 & 40 & 60 \\
\hline
\end{tabular}

The amount of seed sowing in each experiment, regardless of the year, in the first autumn date was 500 pcs. $\mathrm{m}^{-2}$, as the cultivars selected for the experiment require such an amount of seeding at this date and under such soil conditions. In the second autumn date, this standard was increased by $10 \%$ $\left(550 \mathrm{pcs} \cdot \mathrm{m}^{-2}\right)$ due to the fact that the plant losses were expected due to frost damage. In spring, however, the sowing rate was the same as in the first autumn sowing date.

After reaching the full maturity by crops, the final harvest was carried out with a field harvester. After harvest, the following features were determined: grain yield per $14 \%$ moisture content, 1000 grain weight (according to PN-68/R-74017), number of grains per plant, number of grains per spike, grain yield per plant, grain yield per spike. In order to determine the technological value of grains after harvest, representative samples of grains were taken using the principles of the PN-72/A74001 standard. In the grain samples, the following traits were determined: the amount of wet gluten, gluten index (IG), falling number, and SDS sedimentation index. The meteorological conditions are presented in Table 4-5. 
Mean monthly temperatures in particular growing periods

Table 4

\begin{tabular}{|c|c|c|c|c|}
\hline \multirow{2}{*}{ Month } & \multicolumn{4}{|c|}{ Temperature $\left({ }^{\mathbf{}} \mathbf{C}\right)$} \\
\cline { 2 - 5 } & $\mathbf{2 0 0 8 / 2 0 0 9}$ & $\mathbf{2 0 0 9 / 2 0 1 0}$ & $\mathbf{2 0 1 0 / 2 0 1 1}$ & Long-term mean \\
\hline X & 8.9 & 6.3 & 4.8 & 7.4 \\
\hline XI & 4.1 & 6.4 & 5.3 & 2.5 \\
\hline XII & 0.5 & -2.4 & -5.5 & -1.7 \\
\hline I & -3.4 & -6.4 & -1.8 & -3.5 \\
\hline II & -1.6 & -3.4 & -5.2 & -2.6 \\
\hline III & 1.5 & 2.4 & 1.4 & 1.4 \\
\hline IV & 9.6 & 8.7 & 9.6 & 7.6 \\
\hline V & 13.0 & 14.5 & 13.8 & 13.7 \\
\hline VI & 16.1 & 17.9 & 18.4 & 16.5 \\
\hline VII & 19.6 & 21.6 & 18.7 & 18.6 \\
\hline VIII & 17.3 & 20.0 & 18.5 & 17.7 \\
\hline
\end{tabular}

Table 5

Sum of rainfalls in particular vegetation periods

\begin{tabular}{|c|c|c|c|c|}
\hline \multirow{2}{*}{ Month } & \multicolumn{4}{|c|}{ Rainfall (mm) } \\
\cline { 2 - 5 } & $\mathbf{2 0 0 8 / 2 0 0 9}$ & $\mathbf{2 0 0 9 / 2 0 1 0}$ & $\mathbf{2 0 1 0 / 2 0 1 1}$ & Long-term mean \\
\hline X & 52.8 & 99.7 & 12.3 & 40.0 \\
\hline XI & 25.4 & 57.6 & 88.0 & 36.0 \\
\hline XII & 35.1 & 63.8 & 36.5 & 33.0 \\
\hline I & 23.1 & 44.1 & 36.5 & 29.0 \\
\hline II & 41.0 & 38.7 & 31.3 & 25.0 \\
\hline III & 68.4 & 16.7 & 11.2 & 26.0 \\
\hline IV & 5.2 & 23.0 & 37.6 & 36.0 \\
\hline V & 82.8 & 126.8 & 61.2 & 58.0 \\
\hline VI & 198.3 & 67.7 & 65.4 & 68.0 \\
\hline VII & 46.1 & 48.2 & 201.6 & 75.0 \\
\hline VIII & 61.8 & 111.4 & 50.5 & 67.0 \\
\hline
\end{tabular}

The aim of the research was to determine the effect of the sowing date on the yield, yield structure and the technological value of the grains of selected spring wheat varieties.

The results were statistically analyzed using a one-way ANOVA, using the Statgraphics Centurion XVI computer program. Significance of differences between means were evaluated using the Tukey test at the level of significance $p=0.05$.

\section{Results and discussion}

In the 2008/2009 season, wheat sown at the second term (II) did not emerge and the average grain yield of the other two dates did not differ significantly (Table 6). The lack of emergence can be explained by the fact that the temperatures were too low for grains to germinate, which was also accompanied by the lack of snow cover. The response of cultivars to the sowing date was not the same, which was most visible in the case of Cytra cultivar, whose grain yield in autumn sowing conditions was significantly lower than the yield of other cultivars, while of Tybalt cultivar, it was significantly higher in spring sowing conditions. In the second season (harvest 2010), the date of sowing significantly affected the grain yield. The highest yields were obtained by sowing in November. On the other hand, the yields from October (the first term - I) and spring (the third termIII) sowings were significantly lower. Significant varietal differences were also found. The highest grain yields were obtained from Tybalt cultivar and the lowest from Bombona cultivar. The difference between the yields of these cultivars was $1.48 \mathrm{t} \cdot \mathrm{ha}^{-1}$. In the 2010/2011 season, the date of sowing differentiated the yield of grain. The delay in the first autumn date by 2-3 weeks caused a decrease in the yield by over $0.5 \mathrm{t} \cdot \mathrm{ha}^{-1}$ on average. The grain yield obtained from spring sowing was lower than 
that from autumn sowing by $1.07 \mathrm{t} \cdot \mathrm{ha}^{-1}$ (the first term $-\mathrm{I}$ ) and $0.54 \mathrm{t} \cdot \mathrm{ha}^{-1}$ (the second term - II). There were also cultivar differences; the highest yields were given by the Tybalt cultivar and the lowest by Cytra. The difference in grain yield between these cultivars was $24.5 \%$. Genetic factor, i.e. cultivars, had a significant influence on the level of the obtained grain yields. This was pointed out by the authors dealing with the issue of "facultative crops" [4, 8]. In the Weber and Kaus studies [8], some spring wheat cultivars (Olimpia and Helia) had a tendency to higher yields under late autumn sowing compared to ones from spring sowing, while others (Zebra, Torka and Nawra) showed an opposite tendency, and were thus defined by the authors as unsuitable for autumn sowing. One of the cultivars, despite its increased frost resistance (Olimpia), was also included in the group of cultivars unsuitable for autumn sowing, the reason being its high instability of yields. In these studies, winter wheat cultivars were used for comparison. None of the spring wheat cultivars tested at that time equalled the yield of winter wheat cultivars.

Three varieties (Tybalt, Monsun, Bombona) used in own research were also the object of other studies, which were aimed at assessing their suitability for autumn sowing [10]. The authors stated that the tested genotypes can be considered potentially optional, and the yield of grain from autumn sowing was $20.8 \%$ higher than from spring sowing. The majority of researchers assessed the usefulness of cereal cultivars for autumn sowing compared to the effect of their sowing in the spring term. The amount of grain yield increase, as determined in such comparisons, was very diversified. According to Ozturk et al. [11], late autumn sowing of facultative cultivars increased yields by about $37 \%$ as compared to the results from spring sowing. Also Grocholski et al. [2] indicated that the advantage of autumn sowing over spring sowing in terms of wheat yields was very high. In this study, the grain yield of Hena cultivar at autumn sowing was by 1.14 higher, and of Triso cultivar by as much as $2.93 \mathrm{t} \cdot \mathrm{ha}^{-1}$ than in the spring term. Kardasz et al. [4] obtained very high yield increases as a result of autumn sowing instead of the spring one of spring wheat, ranging from $43.2 \%$ to $65.6 \%$, depending on a cultivar.

Table 6

Grain yield of spring wheat $\left(t \cdot h^{-1}\right)$

\begin{tabular}{|c|c|c|c|c|c|c|c|}
\hline \multirow{2}{*}{ Year } & \multirow{2}{*}{\begin{tabular}{|l|} 
Sowing \\
term (A)
\end{tabular}} & \multicolumn{6}{|c|}{ Cultivar (B) } \\
\hline & & Tybalt & Cytra & Bombona & Monsun & Parabola & Mean \\
\hline \multirow{3}{*}{2009} & I & 6.26 & 3.60 & 6.12 & 6.13 & 5.28 & 5.48 \\
\hline & II & - & - & - & - & - & - \\
\hline & III & 6.01 & 5.56 & 5.61 & 5.60 & 5.39 & 5.63 \\
\hline \multicolumn{2}{|c|}{ Mean } & 6.13 & 4.58 & 5.86 & 5.86 & 5.33 & - \\
\hline \multicolumn{8}{|c|}{$\mathrm{LSD}_{0.05}$ for $\mathrm{A}=$ n.s.; $\mathrm{B}=0.473 ; \mathrm{B} / \mathrm{A}=0.769$} \\
\hline \multirow{3}{*}{2010} & I & 7.47 & 6.30 & 5.56 & 6.76 & 6.19 & 6.46 \\
\hline & II & 8.10 & 6.78 & 6.51 & 7.19 & 7.10 & 7.14 \\
\hline & III & 6.69 & 5.59 & 5.76 & 6.72 & 6.46 & 6.24 \\
\hline \multicolumn{2}{|c|}{ Mean } & 7.42 & 6.22 & 5.94 & 6.89 & 6.58 & - \\
\hline \multicolumn{8}{|c|}{$\mathrm{LSD}_{0.05}$ for $\mathrm{A}=0.108 ; \mathrm{B}=0.273 ; \mathrm{B} / \mathrm{A}=0.473$} \\
\hline \multirow{3}{*}{2011} & $\mathrm{I}$ & 5.19 & 4.06 & 4.43 & 4.84 & 4.56 & 4.61 \\
\hline & II & 4.76 & 3.01 & 3.74 & 4.58 & 4.27 & 4.07 \\
\hline & III & 3.80 & 3.30 & 3.33 & 3.71 & 3.55 & 3.54 \\
\hline \multicolumn{2}{|c|}{ Mean } & 4.58 & 3.46 & 3.83 & 4.38 & 4.12 & - \\
\hline & & 0.05 fo & $=0.5$ & $=0.76$ & $\mathrm{~A}=\mathrm{n} . \mathrm{s}$ & & \\
\hline
\end{tabular}

n.s. - not significant $(p=0.05)$

In Cicibór Duży in 2009, the plants that survived the winter period were significantly more tillered than those from spring sowing (Table 7). Bombona cultivar turned out to be the one that developed the most productive shoots in the above-mentioned year, while significantly smaller tillering was noted for Cytra and Parabola cultivars. In the case of the other two cultivars, the decrease in tillering was a trend (the difference was statistically insignificant). Research results from 2010 and 2011 indicate that significantly lower tillering occurred in the case of spring sowing of wheat cultivars than in autumn sowing. The influence of cultivars on the discussed feature was insignificant. The relatively largest differences in the number of plants between autumn and spring sowing treatments 
were found in the experiments set up on the lightest soil in Cicibór Duży, but in this location, the number of plants in autumn sowing was only by $15-20 \%$ lower than in the spring one. Some authors [4] drew attention to the cases of the reverse relation - a higher number of plants under autumn sowing, which was explained by a smaller falling number of plants, which were better rooted and more resistant to moisture deficiency than plants from autumn sowing. In the studies by Kardasz et al. [4], spring wheat sown in autumn also developed a higher number of spikes per unit area compared to the spring sowing. Fotyma [12], comparing the density of spikes per unit area in winter and spring wheat, found a higher number of spikes in the winter forms of this species, but this regularity was modified over the years, which was caused by a partial damage of plants by frost in winter periods. Contrary to these results, the effect of frost damage on the structure of the canopy was insignificant in our studies.

Table 7

Production tillering of spring wheat

\begin{tabular}{|c|c|c|c|c|c|c|c|}
\hline \multirow{2}{*}{ Year } & \multirow{2}{*}{$\begin{array}{c}\text { Sowing } \\
\text { term (A) }\end{array}$} & \multicolumn{6}{|c|}{ Cultivar (B) } \\
\hline & & Tybalt & Cytra & Bombona & Monsun & Parabola & Mean \\
\hline \multirow{3}{*}{2009} & $\mathrm{I}$ & 1.97 & 1.59 & 1.81 & 1.73 & 1.72 & 1.76 \\
\hline & II & - & - & - & - & - & - \\
\hline & III & 1.44 & 1.57 & 1.97 & 1.83 & 1.31 & 1.62 \\
\hline \multicolumn{2}{|c|}{ Mean } & 1.70 & 1.58 & 1.88 & 1.78 & 1.52 & - \\
\hline \multicolumn{8}{|c|}{$\mathrm{LSD}_{0.05}$ for $\mathrm{A}=0.120 ; \mathrm{B}=0.230 ; \mathrm{B} / \mathrm{A}=\mathrm{n} . \mathrm{s}$} \\
\hline \multirow{3}{*}{$\begin{array}{l}\text { Synthesis } \\
\text { from years } \\
2010-2011\end{array}$} & I & 1.62 & 1.50 & 1.62 & 1.78 & 1.61 & 1.62 \\
\hline & II & 1.66 & 1.64 & 1.54 & 1.79 & 1.74 & 1.67 \\
\hline & III & 1.24 & 1.25 & 1.33 & 1.27 & 1.21 & 1.26 \\
\hline \multicolumn{2}{|c|}{ Mean } & 1.50 & 1.45 & 1.49 & 1.58 & 1.49 & - \\
\hline
\end{tabular}

n.s. - not significant $(p=0.05)$

In 2009 in Cicibór Duży, a significantly higher weight of 1000 grains of wheat sown in spring (Table 8) was recorded. In the other two years, a lower weight of 1000 grains was obtained for the treatments with spring sowing. The weight of 1000 grains was very varied depending on a wheat cultivar. The highest weight of 1000 grains in 2009 was recorded for Parabola, and in the next two years, for Monsun. Grocholski et al. [2] and Kardasz et al. [4] found a positive effect of autumn date of spring wheat sowing on the weight of 1000 grains. Similar results were obtained by Wenda Piesik et al. [10]. The average value of the weight of thousands grains coming from autumn sowing was 42.7 $\mathrm{g}$, while that of spring sowing $31.7 \mathrm{~g}$. Long-term research results, obtained from microfield experiments with numerous winter cereal cultivars, indicate that the delay in their sowing date leads to a number of unfavourable changes in the growth and development of plants and, as a result, to a decrease in the weight of 1000 grains [6, 13-15].

Table 8

Weight of 1000 grains (g) of spring wheat

\begin{tabular}{|c|c|c|c|c|c|c|c|}
\hline \multirow{2}{*}{ Year } & \multirow{2}{*}{$\begin{array}{l}\text { Sowing } \\
\text { term (A) }\end{array}$} & \multicolumn{6}{|c|}{ Cultivar (B) } \\
\hline & & Tybalt & Cytra & Bombona & Monsun & Parabola & Mean \\
\hline \multirow{3}{*}{2009} & I & 36.25 & 24.46 & 36.29 & 35.54 & 37.04 & 33.91 \\
\hline & II & - & - & - & - & - & - \\
\hline & III & 34.97 & 30.38 & 34.91 & 34.73 & 42.15 & 35.43 \\
\hline \multicolumn{2}{|l|}{ Mean } & 35.61 & 27.42 & 35.60 & 35.13 & 39.60 & - \\
\hline \multicolumn{8}{|c|}{$\mathrm{LSD}_{0.05}$ for $\mathrm{A}=1.500 ; \mathrm{B}=8.700 ; \mathrm{B} / \mathrm{A}=4.080$} \\
\hline \multirow{3}{*}{$\begin{array}{c}\text { Synthesis from } \\
\text { years } \\
2010-2011 \\
\end{array}$} & I & 43.77 & 40.81 & 38.19 & 42.69 & 50.86 & 43.26 \\
\hline & II & 39.74 & 39.82 & 39.41 & 43.84 & 48.25 & 42.21 \\
\hline & III & 37.06 & 34.00 & 37.36 & 42.07 & 44.49 & 38.99 \\
\hline \multicolumn{2}{|l|}{ Mean } & 40.19 & 38.21 & 38.32 & 42.86 & 47.87 & - \\
\hline
\end{tabular}

n.s. - not significant $(\mathrm{p}=0.05)$ 
The weight of grains per plant depended unequivocally on the experimental factors in particular years of research (Table 9). In 2009, this feature was similar in plants from autumn and spring sowing dates. The interaction of the sowing date and wheat cultivar was found, which was manifested by a much higher value of this feature in the plants of Tybalt cultivar in the treatments with the first (I) sowing date. In 2010, together with the delayed sowing date, the grain weight per plant was getting lower and lower. The differences were significant; between the first (I) and second (II) terms it was $13.1 \%$, while between the first (I) and third (III) $-46.3 \%$. The highest weight of grains per plant was recorded for the cultivar Monsun, while the lowest for the cultivar Bombona. The difference between these cultivars was $23.2 \%$. In 2011, the values of this feature for wheat from autumn sowing did not differ significantly, while from spring sowing it was significantly lower. Wheat cultivar Cytra had the weight of grains per plant significantly higher than other cultivars. Sowing in spring resulted in a decrease of grain yield per plant and per spike. This is consistent with the results of Sułek et al. [16], who found a lower grain yield per spike as a result of moving the date of spring wheat sowing from autumn to spring.

Table 9

Weight of grains per plant (g)

\begin{tabular}{|c|c|c|c|c|c|c|c|}
\hline \multirow{2}{*}{ Year } & \multirow{2}{*}{$\begin{array}{l}\text { Sowing } \\
\text { term (A) }\end{array}$} & \multicolumn{6}{|c|}{ Cultivar (B) } \\
\hline & & Tybalt & Cytra & Bombona & Monsun & Parabola & Mean \\
\hline \multirow{3}{*}{2009} & I & 2.11 & 1.40 & 1.62 & 1.79 & 1.51 & 1.68 \\
\hline & II & - & - & - & - & - & - \\
\hline & III & 1.64 & 1.60 & 1.54 & 1.55 & 1.33 & 1.53 \\
\hline \multicolumn{2}{|c|}{ Mean } & 1.87 & 1.50 & 1.58 & 1.67 & 1.42 & - \\
\hline \multicolumn{8}{|c|}{$\mathrm{LSD}_{0.05}$ for $\mathrm{A}=0.120 ; \mathrm{B}=0.280 ; \mathrm{B} / \mathrm{A}=0.460$} \\
\hline \multirow{3}{*}{2010} & I & 4.04 & 3.11 & 2.87 & 3.80 & 3.47 & 3.45 \\
\hline & II & 2.93 & 2.91 & 2.43 & 3.37 & 3.43 & 3.01 \\
\hline & III & 1.98 & 1.77 & 1.67 & 1.90 & 2.00 & 1.86 \\
\hline \multicolumn{2}{|c|}{ Mean } & 2.98 & 2.59 & 2.32 & 3.02 & 2.96 & - \\
\hline \multicolumn{8}{|c|}{$\mathrm{LSD}_{0.05}$ for $\mathrm{A}=0.380 ; \mathrm{B}=0.450 ; \mathrm{B} / \mathrm{A}=1.030$} \\
\hline \multirow{3}{*}{2011} & I & 1.81 & 2.45 & 1.50 & 1.75 & 1.68 & 1.83 \\
\hline & II & 1.86 & 2.41 & 1.50 & 1.90 & 1.73 & 1.88 \\
\hline & III & 1.33 & 2.10 & 1.01 & 1.52 & 1.31 & 1.45 \\
\hline \multicolumn{2}{|c|}{ Mean } & 1.66 & 2.32 & 1.33 & 1.72 & 1.57 & - \\
\hline \multicolumn{8}{|c|}{$\operatorname{LSD}_{0.05}$ for $\mathrm{A}=0.320 ; \mathrm{B}=0.330 ; \mathrm{B} / \mathrm{A}=0.490$} \\
\hline
\end{tabular}

The falling number is an indicator, which value is usually connected in practice with the problem of sprouting [17]. Cacak-Pietrzak [18] states that the value of the falling number in the range of 220$270 \mathrm{~s}$ indicates the optimal activity of amylolytic enzymes in grain processed into flour for bread baking. In 2009, the falling number of wheat grain depended on the selection of a spring wheat cultivar (Table 10). The highest falling number was observed for Parabola cultivar grains, while the lowest for Bombona cultivar, respectively 456 and $378 \mathrm{~s}$. The difference was $17.1 \%$. Under wheat sowing in October and spring, the highest value of this feature was found for the grains of Parabola cultivar. The grains of Cytra, Bombona and Monsun cultivars were characterized by a higher value of the falling number at the autumn sowing term. In the next year, the sowing date also had no significant effect on the value of this feature. The biggest mean falling number was recorded for the grains of Parabola and Cytra cultivars, while the lowest of Bombona cultivar. In the case of the first two wheat cultivars, together with the delay in sowing date, the falling number increased. In 2011, the value of the falling number was significantly influenced by the selection of a cultivar for sowing. The grains of the Monsun cultivar were characterized by the highest value of this index, while the grains of Cytra, the lowest. The difference was $56.5 \%$. At all sowing dates, the highest values of the falling number were recorded for the grains of the Monsun cultivar. In Szafrańska's study [19], the falling number of winter and spring wheat grains from the 2009-2011 harvest ranged from 87 to 393 seconds. The author did not find any significant differences in the number of falling number depending on the year of harvest. Rothkaehl et al. [20, 21, 22] and Szafrańska [23] did not find any significant differences in the 
falling number depending on the wheat cultivar. In the research by Nowak et al. [24], the grains of spring wheat cultivars had a very high falling number (over $320 \mathrm{~s}$ ), which indicates their low amylolytic activity. At the same time, it was found that the value of this trait depended significantly on different habitat conditions in which different spring wheat cultivars were grown. Studies by CacakPietrzak et al. [25] indicated that the value of this feature in spring wheat was primarily influenced by the varietal factor. In wheat grains of Katoda, Lagwa and Waluta cultivars, the activity of amylolytic enzymes was low (less than 300 s), whereas in Ostka Smolicka cultivar it was at a medium level (273 s). The results of earlier studies [14;26-29] also indicated that this feature is primarily influenced by the varietal factor and weather conditions during both plant growth and grain harvest.

Table 10

Falling number (s) of spring wheat grains

\begin{tabular}{|c|c|c|c|c|c|c|c|}
\hline \multirow{2}{*}{ Year } & \multirow{2}{*}{$\begin{array}{l}\text { Sowing } \\
\text { term (A) }\end{array}$} & \multicolumn{6}{|c|}{ Cultivar (B) } \\
\hline & & Tybalt & Cytra & Bombona & Monsun & Parabola & Mean \\
\hline \multirow{3}{*}{2009} & $\mathrm{I}$ & 364 & 429 & 383 & 405 & 445 & 405 \\
\hline & II & - & - & - & - & - & - \\
\hline & III & 414 & 406 & 374 & 386 & 468 & 409 \\
\hline \multicolumn{2}{|c|}{ Mean } & 389 & 418 & 378 & 395 & 456 & - \\
\hline \multicolumn{8}{|c|}{$\mathrm{LSD}_{0.05}$ for $\mathrm{A}=$ n.s.; $\mathrm{B}=27.0 ; \mathrm{B} / \mathrm{A}=38.1$} \\
\hline \multirow{3}{*}{2010} & I & 376 & 406 & 345 & 400 & 401 & 385 \\
\hline & II & 380 & 409 & 349 & 381 & 414 & 386 \\
\hline & III & 391 & 430 & 330 & 351 & 431 & 386 \\
\hline \multicolumn{2}{|c|}{ Mean } & 382 & 415 & 341 & 377 & 415 & - \\
\hline \multicolumn{8}{|c|}{$\mathrm{LSD}_{0.05}$ for $\mathrm{A}=$ n.s.; $\mathrm{B}=14.5 ; \mathrm{B} / \mathrm{A}=25.1$} \\
\hline \multirow{3}{*}{2011} & I & 246 & 153 & 185 & 289 & 209 & 217 \\
\hline & II & 266 & 129 & 184 & 299 & 234 & 222 \\
\hline & III & 258 & 110 & 199 & 316 & 209 & 219 \\
\hline \multicolumn{2}{|c|}{ Mean } & 257 & 131 & 189 & 301 & 217 & - \\
\hline
\end{tabular}

n.s. - not significant $(p=0.05)$

In the first year of the study, the sowing date had no significant effect on the amount of wet gluten washed out of wheat grain (Table 11). Significant differences between cultivars were found. The highest amount of wet gluten was found in the grains of Parabola cultivar, while the lowest in Monsun cultivar. The difference between these cultivars was $14.9 \%$. An interaction between the experimental factors was also found. Grains of Cytra cultivar from the autumn sowing date were characterized by a higher value of this feature compared to the grains from the spring date. On the other hand, in 2010, a higher mean value of this trait $(27.2 \%)$ was found for the grains from spring sowing date than for autumn sowing. Comparing the differences between cultivars, the highest amount of wet gluten was found in the grain of the Bombona cultivar while the lowest in Monsun cultivar. The difference was $17.5 \%$ and was statistically significant. In 2011, together with the delay in sowing, the amount of wet gluten in the grains of the examined spring wheat cultivars, increased. The difference between the first (I) and second (II) date was $6.9 \%$, while between the second (II) and third (III) $-6.7 \%$. The highest productivity of wet gluten was found in the case of Cytra cultivar, while the lowest in the case of Monsun cultivar. In the seeds of Cytra, Bombona and Monsun cultivars the amount of wet gluten increased together with the delay in sowing date. Cacak-Pietrzak [18] stated that wheat flour should not be used in bakeries where the amount of wet gluten is less than $25 \%$. Therefore, in order to ensure this level of gluten in flour, the minimum amount of gluten in the grains should be about $27 \%$.

Cacak-Pietrzak et al. [30] and Podolska and Sułek [31] state that one of the main criteria for assessing the technological suitability of wheat grain is the assessment of protein and gluten content. According to Borkowska et al. [32] and Małecka and Blecharczyk [33] changes in wet gluten content in spring and winter wheat grain depend on the weather conditions in the years of research. 
Wet gluten quantity $(\%)$ in spring wheat grains

\begin{tabular}{|c|c|c|c|c|c|c|c|}
\hline \multirow{2}{*}{ Year } & \multirow{2}{*}{$\begin{array}{c}\text { Sowing } \\
\text { term (A) }\end{array}$} & \multicolumn{6}{|c|}{ Cultivar (B) } \\
\hline & & Tybalt & Cytra & Bombona & Monsun & Parabola & Mean \\
\hline \multirow{3}{*}{2009} & I & 26.0 & 28.0 & 25.5 & 24.0 & 26.0 & 25.9 \\
\hline & II & - & - & - & - & - & - \\
\hline & III & 27.0 & 26.5 & 28.0 & 24.5 & 31.0 & 27.4 \\
\hline \multicolumn{2}{|c|}{ Mean } & 26.5 & 27.3 & 26.8 & 24.3 & 28.5 & \\
\hline \multicolumn{8}{|c|}{$\mathrm{LSD}_{0.05}$ for $\mathrm{A}=$ n.s.; $\mathrm{B}=0.86 ; \mathrm{B} / \mathrm{A}=1.22$} \\
\hline \multirow{3}{*}{2010} & I & 23.0 & 24.0 & 25.0 & 20.5 & 23.5 & 23.2 \\
\hline & II & 22.5 & 22.0 & 25.0 & 21.0 & 24.0 & 22.9 \\
\hline & III & 23.5 & 27.5 & 27.0 & 22.0 & 26.0 & 25.2 \\
\hline \multicolumn{2}{|c|}{ Mean } & 23.0 & 24.5 & 25.7 & 21.2 & 24.5 & - \\
\hline \multicolumn{8}{|c|}{$\mathrm{LSD}_{0.05}$ for $\mathrm{A}=0.83 ; \mathrm{B}=0.75 ; \mathrm{B} / \mathrm{A}=1.30$} \\
\hline \multirow{3}{*}{2011} & I & 27.6 & 31.2 & 30.3 & 25.5 & 29.9 & 28.9 \\
\hline & II & 26.9 & 36.1 & 34.1 & 27.2 & 31.2 & 31.1 \\
\hline & III & 31.5 & 36.8 & 37.4 & 30.5 & 30.6 & 33.4 \\
\hline \multicolumn{2}{|c|}{ Mean } & 28.7 & 34.7 & 33.9 & 27.8 & 30.6 & - \\
\hline & & $\mathrm{SD}_{0.0}$ & $\mathrm{~A}=0$ & $B=0$. & $=0.85$ & & \\
\hline
\end{tabular}

n.s. - not significant $(p=0.05)$

In the first year of the study, the sowing date had no significant effect on the quality of gluten (IG) in wheat grains (Table 12), but under the autumn sowing date, slightly higher index values were found. Among the wheat cultivars studied, only the grains of Cytra cultivar were characterized by a significantly lower gluten index in comparison to other cultivars. In the next two years of the study, the choice of cultivar had a significant influence on the value of this feature. The highest mean values of this index were found for the grains of the Monsun cultivar, while the lowest for the Cytra cultivar. The difference between these cultivars in the range of this feature was $57.5 \%$.

Table 12

Gluten index of spring wheat grains

\begin{tabular}{|c|c|c|c|c|c|c|c|}
\hline \multirow{2}{*}{ Year } & \multirow{2}{*}{$\begin{array}{c}\text { Sowing } \\
\text { term (A) }\end{array}$} & \multicolumn{6}{|c|}{ Cultivar (B) } \\
\hline & & Tybalt & Cytra & Bombona & Monsun & Parabola & Mean \\
\hline \multirow{3}{*}{2009} & $\mathrm{I}$ & 85 & 35 & 93 & 85 & 92 & 78 \\
\hline & II & - & - & - & - & - & - \\
\hline & III & 79 & 8 & 85 & 70 & 69 & 62 \\
\hline \multicolumn{2}{|l|}{ Mean } & 82 & 22 & 89 & 77 & 80 & - \\
\hline \multicolumn{8}{|c|}{$\mathrm{LSD}_{0.05}$ for $\mathrm{A}=$ n.s.; $\mathrm{B}=25.0 ; \mathrm{B} / \mathrm{A}=$ n.s. } \\
\hline \multirow{3}{*}{$\begin{array}{c}\text { Synthesis from years } \\
\text { 2010-2011 }\end{array}$} & I & 89 & 41 & 71 & 90 & 82 & 75 \\
\hline & II & 75 & 38 & 87 & 86 & 81 & 73 \\
\hline & III & 84 & 32 & 85 & 86 & 84 & 74 \\
\hline \multicolumn{2}{|l|}{ Mean } & 83 & 37 & 81 & 87 & 82 & - \\
\hline
\end{tabular}

n.s. - not significant $(p=0.05)$

The SDS sedimentation index is a parameter, which value depends on the quality and the amount of gluten. In the first year of the study, the sowing date did not significantly differentiate the SDS sedimentation index of wheat grain (Table 13). The choice of a cultivar for sowing had a significant influence on the value of this index. The highest mean value of SDS sedimentation index was found for the grains of Parabola cultivar, while the lowest for the grains of Cytra cultivar. The difference was $29.1 \%$. Among the tested wheat cultivars, only the grains of Cytra cultivar at the first autumn sowing date, was characterized by a higher value of this index, as compared to the spring date. In 2010, higher SDS sedimentation index values were found for autumn sowing dates. Among the examined wheat cultivars, the highest mean value of this index was found for the grains of Bombona and Parabola 
cultivars, while the lowest for Cytra cultivar. The difference between these cultivars was $28.7 \%$. In 2011, the value of the SDS sedimentation index of the grains from all sowing dates was at a similar level. Analyzing the differences between cultivars, it was found that the highest mean value of this trait was found for Parabola and Bombona cultivars, while the lowest for Cytra cultivar. The difference in this feature was $27 \%$. It was observed that the value of the sedimentation index is a varietal feature, which is confirmed by the results of the study by Cacak-Pietrzak et al. [25] and Ceglińska et al. [34].

Table 13

SDS sedimentation index $\left(\mathrm{cm}^{3}\right)$ of spring wheat grain

\begin{tabular}{|c|c|c|c|c|c|c|c|}
\hline \multirow{2}{*}{ Year } & \multirow{2}{*}{$\begin{array}{l}\text { Sowing } \\
\operatorname{term}(\mathbf{A})\end{array}$} & \multicolumn{6}{|c|}{ Cultivar (B) } \\
\hline & & Tybalt & Cytra & Bombona & Monsun & Parabola & Mean \\
\hline \multirow{3}{*}{2009} & I & 50 & 45 & 55 & 55 & 61 & 53 \\
\hline & II & - & - & - & - & - & - \\
\hline & III & 56 & 41 & 60 & 56 & 61 & 55 \\
\hline \multicolumn{2}{|c|}{ Mean } & 53 & 43 & 57 & 55 & 61 & - \\
\hline \multicolumn{8}{|c|}{$\mathrm{LSD}_{0.05}$ for $\mathrm{A}=$ n.s.; $\mathrm{B}=4.3 ; \mathrm{B} / \mathrm{A}=8.8$} \\
\hline \multirow{3}{*}{2010} & I & 63 & 49 & 65 & 64 & 72 & 62 \\
\hline & II & 60 & 52 & 69 & 66 & 66 & 63 \\
\hline & III & 57 & 45 & 71 & 61 & 68 & 60 \\
\hline \multicolumn{2}{|c|}{ Mean } & 60 & 49 & 68 & 64 & 68 & - \\
\hline \multicolumn{8}{|c|}{$\mathrm{LSD}_{0.05}$ for $\mathrm{A}=2.2 ; \mathrm{B}=2.1 ; \mathrm{B} / \mathrm{A}=3.6$} \\
\hline \multirow{3}{*}{2011} & $\mathrm{I}$ & 79 & 59 & 83 & 82 & 84 & 77 \\
\hline & II & 82 & 60 & 82 & 77 & 81 & 76 \\
\hline & III & 75 & 62 & 80 & 82 & 84 & 77 \\
\hline \multicolumn{2}{|c|}{ Mean } & 79 & 60 & 82 & 80 & 83 & - \\
\hline
\end{tabular}

n.s. - not significant $(p=0.05)$

\section{Conclusions}

1. In 2010 and 2011 significantly higher grain yields and 1000 grain weight were observed in wheat from autumn sowing dates, which proves the legitimacy of sowing selected spring wheat during the autumn.

2. The autumn sowing date resulted in better plant production tillering and higher grain weight per plant.

3. The quality of grain from both autumn and spring dates was similar. The sowing date did not significantly affect the falling number and gluten index.

4. The amount of wet gluten and SDS sedimentation index depended on the year of research, which proves that the weather conditions influenced these values.

\section{References}

[1] Rudnicki F., Jaskulski D., Dębowski G. Reakcje odmian pszenicy jarej na termin siewu i nawożenie azotem w warunkach posusznych (Reactions of spring wheat varieties for the sowing date and nitrogen fertilization in dry conditions). Roczniki Nauk Rolniczych A 114 (3-4), 1999, 97-107. (In Polish)

[2] Grocholski J., Sowiński J., Kulczycki G., Wardęga S. Wpływ terminu siewu przewódkowych odmian pszenicy uprawianych na glebie pyłowo-ilastej na plon i parametry morfologiczne roślin (The Effect of Sowing Date of Facultative Wheat Varieties Cultivated on Silt-loam Soil on Yield and Plant). Zeszyty Nauk AR we Wrocławiu, Rolnictwo XCI, 560, 2007, pp. 7-12. (In Polish)

[3] Kurowski T. P., Bruderek A. Zdrowotność pszenicy jarej w zależności od terminu siewu i odmiany (Healthiness of spring wheat depending on the sowing date and variety). Postępy $\mathrm{w}$ Ochronie Roślin, 49 (1), 2009, pp. 224-227. (In Polish)

[4] Kardasz P., Bubniewicz P., Bączkowska E. Ocena stanu zachwaszczenia i plonowanie czterech odmian pszenicy jarej przewódkowej wysianych w różnych terminach (Evaluation of weed 
infestation and yielding of four spring wheat varieties sown at different dates). Postępy w Ochronie Roślin, 50 (3), 2010, pp. 1366-1374. (In Polish)

[5] Wyzińska M., Grabiński J. The influence of autumn sowing date on the productivity of spring wheat (Triticum aestivum L.). Research for Rural Development 2018, Annual 24th International Scientific Conference Proceedings, 2, 2018, pp. 35-41.

[6] Grabiński J., Wyzińska M. The effect of superabsorbent polimer application on yielding of winter wheat (Triticum aestivum L.). Research for Rural Development 2018, Annual $24^{\text {th }}$ International Scientific Conference Proceedings, 2, 2018, pp. 55-61.

[7] Hnilička F., Petr J., Hniličková H., Martinková J. The yield formation in the alternative varieties of wheat. Chech J. Genet. Plant Breed., 41, 2005, pp. 295-301.

[8] Weber R., Kaus A. Plonowanie odmian pszenicy jarej w zależności od terminu siewu w warunkach południowo-zachodniej Polski (Yielding varieties of spring wheat depending on the sowing date in the conditions of south-western Poland). Fragmenta Agronomica, XXIV, 2(94), 2007, pp. 372-380. (In Polish)

[9] Wenda-Piesik A., Wasilewski P. Reakcja pszenicy jarej „Monsun” i żyta jarego „Bojko” na późnojesienne terminy siewu (Reaction of spring wheat "Monsun" and spring rye "Bojko" for late autumn seeding dates). Zeszyty Problemowe Postępów Nauk Rolniczych 580, 2015, pp. 149-159. (In Polish)

[10] Wenda-Piesik A., Holkova L., Solarova E., Pokorny R. Attributes of wheat cultivars for late autumn sowing genes expression and field estimates. European Journal of Agronomy, 75, 2016, pp. 42-49.

[11] Ozturk A., Caglar O., Bulut S. Growth and field response of facultative wheat to winter sowing, freezing sowing and spring sowing at different seeding rates. Journal of Agronomy \& Crop Science, 192, 2006, pp. 10-16. (In Polish)

[12]Fotyma E. Porównanie produktywności pszenicy ozimej i jarej uprawianej w różnych warunkach agroekologicznych (Comparison of productivity of winter and spring wheat cultivated in various agro-ecological conditions). Fragmenta Agronomica, 3(79), 2003, pp. 98-114. (In Polish)

[13] Mazurek J., Sułek A. Plon i cechy struktury plonu odmian i rodów pszenicy jarej w zależności od terminu siewu (Yield and yield structure of varieties of spring wheat depending on the sowing date). Biuletyn IHAR, 194, 2000, pp. 79-83. (In Polish)

[14] Sułek A. Określenie reakcji nowych rodów i odmian pszenicy jarej na wybrane czynniki agrotechniczne (Determination of reactions of new spring wheat cultivars to selected agronomic factors). Biuletyn IHAR, 231, 2004, pp.139-145. (In Polish)

[15] Grabiński. J., Jaśkiewicz B., Podolska G., Sułek A. Termin siewu w uprawie zbóż (The date of sowing in the cultivation of cereals). Studia i raporty IUNG-PIB, 9, 2007, pp. 37-45. (In Polish)

[16] Sułek A., Nieróbca A., Cacak-Pietrzak G. Wpływ terminu siewu na plon i jakość ziarna pszenicy jarej (Influence of the sowing date on yield and quality of spring wheat grain). Polish Journal of Agronomy, 29, 2017, pp. 43-50. (In Polish)

[17] Węgrzyn S., Gut M., Cyganowicz A., Ptak B. Odporność rodów i odmian pszenicy (Triticum aestivum L.) na porastanie. Część I. Pszenica ozima (Resistance of strains and varieties of wheat (Triticum aestivum L.) to sprouting. Part I. Winter wheat). Biuletyn IHAR, 180, 1991, pp. 121129. (In Polish)

[18]Cacak-Pietrzak G. Wykorzystanie pszenicy w różnych gałęziach przemysłu spożywczego wymagania technologiczne (The use of wheat in various branches of the food industry technological requirements). Przegląd Zbożowo-Młynarski, 52 (11), 2008, pp. 11-13. (In Polish)

[19] Szafrańska A. Ocena wartości technologicznej wybranych odmian pszenicy ze zbiorów z lat 2009-2011 (Evaluation of the technological value of selected wheat varieties from the 2009-2011 harvest). Zeszyty Problemowe Postępów Nauk Rolniczych, 571, 2012, pp. 115-126. (In Polish)

[20] Rothkaehl J., Abramczyk D., Górniak W., Stępniewska S. Ocena przydatności technologicznej ziarna pszenicy uprawianej w kraju. Część I. Wstępna ocena podstawowych cech technologicznych ziarna pszenicy ze zbiorów 2009 roku (Evaluation of technological suitability of wheat grain cultivated in the country. Part I. Initial assessment of the basic technological characteristics of wheat grain from the harvest of 2009). Sprawozdanie z realizacji tematu. Maszynopis. IBPRS, Warszawa. 2009. (In Polish) 
[21]Rothkaehl J., Abramczyk D., Górniak W., Stępniewska S. Szafrańska A. Ocena przydatności technologicznej ziarna pszenicy uprawianej w kraju. Część I. Wstępna ocena podstawowych cech technologicznych ziarna pszenicy ze zbiorów 2009 roku (Evaluation of technological suitability of wheat grain cultivated in the country. Part I. Initial assessment of the basic technological characteristics of wheat grain from the harvest of 2009). Sprawozdanie z realizacji tematu. Maszynopis. IBPRS, Warszawa. 2010. (In Polish)

[22] Rothkaehl J., Abramczyk D., Górniak W., Stępniewska S. Szafrańska A. Ocena przydatności technologicznej ziarna pszenicy uprawianej w kraju. Część I. Wstępna ocena podstawowych cech technologicznych ziarna pszenicy ze zbiorów 2009 roku (Evaluation of technological suitability of wheat grain cultivated in the country. Part I. Initial assessment of the basic technological characteristics of wheat grain from the harvest of 2009). Sprawozdanie z realizacji tematu. Maszynopis. IBPRS, Warszawa, 2011. (In Polish)

[23] Szafrańska A. Ocena jakości wybranych odmian pszenicy za pomocą aparatu mixolab (Evaluation of the quality of selected wheat varieties using a mixolab apparatus). Postępy Nauki i Technologii Przemysłu Rolno-Spożywczego, 66 (4), 2011, pp. 5-16. (In Polish)

[24] Nowak W., Zbroszczyk T., Kotowicz L. Wpływ intensywności uprawy na niektóre cechy jakościowe ziarna odmian pszenicy (Effect of cultivation intensity on some quality traits of grains of wheat varieties). Pamiętnik Puławski, 135, 2004, pp. 199-211. (In Polish)

[25] Cacak-Pietrzak G., Sułek A., Gondek E., Sułek A. Plonowanie oraz cechy jakościowe ziarna nowych odmian pszenicy jarej w zależności od poziomu nawożenia azotem (Yielding and quality characteristics of grains of new varieties of spring wheat depending on the level of nitrogen fertilization). Zeszyty Problemowe Postępów Nauk Rolniczych, 553, 2010, pp. 11-19. (In Polish)

[26] Sułek A., Cacak-Pietrzak G., Ceglińska A., Haber T. Wartość technologiczna wybranych odmian pszenicy jarej w zależności od sposobu nawożenia azotem (Technological value of selected spring wheat varieties depending on the method of nitrogen fertilization). Pamiętnik Puławski, 130, 2002, pp. 709-718. (In Polish)

[27] Sułek A., Cacak-Pietrzak G., Ceglińska A. Wpływ różnych sposobów aplikacji azotu na plon, elementy jego struktury oraz wybrane cechy jakościowe ziarna odmian pszenicy jarej (Influence of various nitrogen application methods on yield, elements of its structure and selected qualitative features of wheat seeds of spring wheat varieties). Annales UMCS, Sec. E, 59, 2, 2004, pp. 543551. (In Polish)

[28]Cacak-Pietrzak G., Sułek A. Wpływ poziomu nawożenia azotem na plonowanie i jakość technologiczną ziarna pszenicy jarej (Influence of the nitrogen fertilization level on the yield and technological quality of spring wheat grain). Biuletyn IHAR, 245, 2007, pp. 47-55. (In Polish)

[29] Sułek A., Cacak-Pietrzak G. Kształtowanie się cech jakościowych ziarna odmian pszenicy jarej w zależności od nawożenia azotem (Formation of qualitative features of wheat seeds of spring wheat varieties depending on nitrogen fertilization). Fragmenta Agronomica, 25 (1), 2008, pp. 400-409. (In Polish)

[30] Cacak-Pietrzak G., Ceglińska A., Haber T. Wartość technologiczna wybranych odmian pszenicy ozimej w zależności od zróżnicowanego nawożenia azotem (Technological value of selected winter wheat varieties depending on different nitrogen fertilization). Pamiętnik Puławski, 262, 1999, pp. 81-91. (In Polish)

[31] Podolska G., Sułek A. Główne elementy technologii produkcji decydujące o wysokiej jakości ziarna pszenicy (The main elements of production technology that determine the high quality of wheat grain). Pamiętnik Puławski, 130, 2003, pp. 597-605. (In Polish)

[32] Borkowska H., Grundas S., Styk B. Wysokość i jakość plonów niektórych odmian pszenicy jarej w zależności od nawożenia azotowego (The height and quality of yields of some spring wheat varieties depending on nitrogen fertilization). Annales UMCS, Sec. E, 57, 2002, pp. 99-103. (In Polish)

[33] Małecka I., Blecharczyk A. 2004. Wpływ systemów uprawy roli na jakość ziarna pszenicy ozimej (The impact of tillage systems on the quality of winter wheat grain). Pamiętnik Puławski, 135, 2004, pp. 181-187. (In Polish)

[34]Ceglińska A., Cacak-Pietrzak G., Haber T., Nita Z. Właściwości przemiałowe i wypiekowe wybranych odmian pszenicy ozimej (Milling and baking properties of selected cultivars of winter wheat). Biuletyn IHAR, 218/219, 2001, pp. 179-184. (In Polish) 